\title{
The role of microorganisms on biotransformation of brewers' spent grain
}

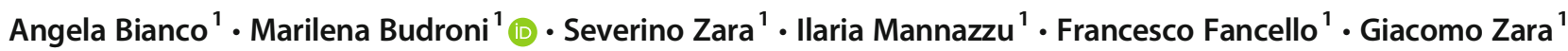

Received: 17 June 2020 / Revised: 7 August 2020 / Accepted: 17 August 2020 / Published online: 2 September 2020

(C) The Author(s) 2020

\begin{abstract}
Brewers' spent grain (BSG) is the most abundant by-product of brewing. Due to its microbiological instability and high perishability, fresh BSG is currently disposed of as low-cost cattle feed. However, BSG is an appealing source of nutrients to obtain products with high added value through microbial-based transformation. As such, BSG could become a potential source of income for the brewery itself. While recent studies have covered the relevance of BSG chemical composition in detail, this review aims to underline the importance of microorganisms from the stabilization/contamination of fresh BSG to its biotechnological exploitation. Indeed, the evaluation of BSG-associated microorganisms, which include yeast, fungi, and bacteria, can allow their safe use and the best methods for their exploitation. This bibliographical examination is particularly focused on the role of microorganisms in BSG exploitation to (1) produce enzymes and metabolites of industrial interest, (2) supplement human and animal diets, and (3) improve soil fertility. Emerging safety issues in the use of BSG as a food and feed additive is also considered, particularly considering the presence of mycotoxins.
\end{abstract}

Key points

- Microorganisms are used to enhance brewers' spent grain nutritional value.

- Knowledge of brewers' spent grain microbiota allows the reduction of health risks.

Keywords Microbial communities $\cdot$ Microbial quality $\cdot$ Mycotoxins $\cdot$ Single-cell protein $\cdot$ Vermicompost $\cdot$ Brewers' spent grain

\section{Introduction}

The recycling and exploitation of brewing residues, such as brewery wastewater, surplus yeast, and brewers' spent grain (BSG), are critical goals for reduction of energy consumption and residue disposal costs, and also for reduction of the associated carbon foot-print (Zupančič et al. 2017). BSG is the most abundant by-product from the brewing process (i.e., $85 \%$ of total by-products) (Fig. 1). Some 100 to $130 \mathrm{~kg}$ of fresh BSG (humidity, 70-80\%) are obtained from $100 \mathrm{~kg}$ of malt, which also equates to 21 to $22 \mathrm{~kg} \mathrm{BSG}$ per hectoliter of beer brewed (Kunze 2004). The global production of BSG has reached 39 million tons per year on average (Birsan et al. 2019). Of this, 3.4 million tons are produced in Europe, which ranges from 2 million tons/year in Germany (Steiner et al.

Marilena Budroni

mbudroni@uniss.it

1 Department of Agricultural Science, University of Sassari, Sassari, Italy
2015 ) to 288,000 tons/year in Italy (Assobirra Annual Report 2018). Around 70\% of the BSG produced is used as animal feed, with $10 \%$ used to produce biogas and the remaining $20 \%$ disposed of as landfill. Its relatively low cost makes BSG an interesting raw material that has the potential to be used for the production of goods with high added value.

Brewers' spent grain comprises the glumes, pericarp, and integuments of the outer layers of the barley kernels and of the other cereals, which contain nutrients that are not extracted during the malting and mashing processes (Fig. 2) (dos Santos Mathias et al. 2014). The chemical composition of BSG (Table 1) varies depending on barley cultivar, malting process, and quality and formulation of the brewing cereals (Gupta et al. 2010; Santos et al. 2003). Notwithstanding, BSG composition always includes high levels of dietary fiber, protein, and essential amino acids, as well as appreciable levels of minerals, polyphenols, vitamins, and lipids (Fărcaș et al. 2014). The high polysaccharide, protein, and moisture content of BSG makes it susceptible to microbial deterioration over a short period of time (i.e., from 2 to 7 days) (Wang et al. 2014; Gupta et al. 2013). 


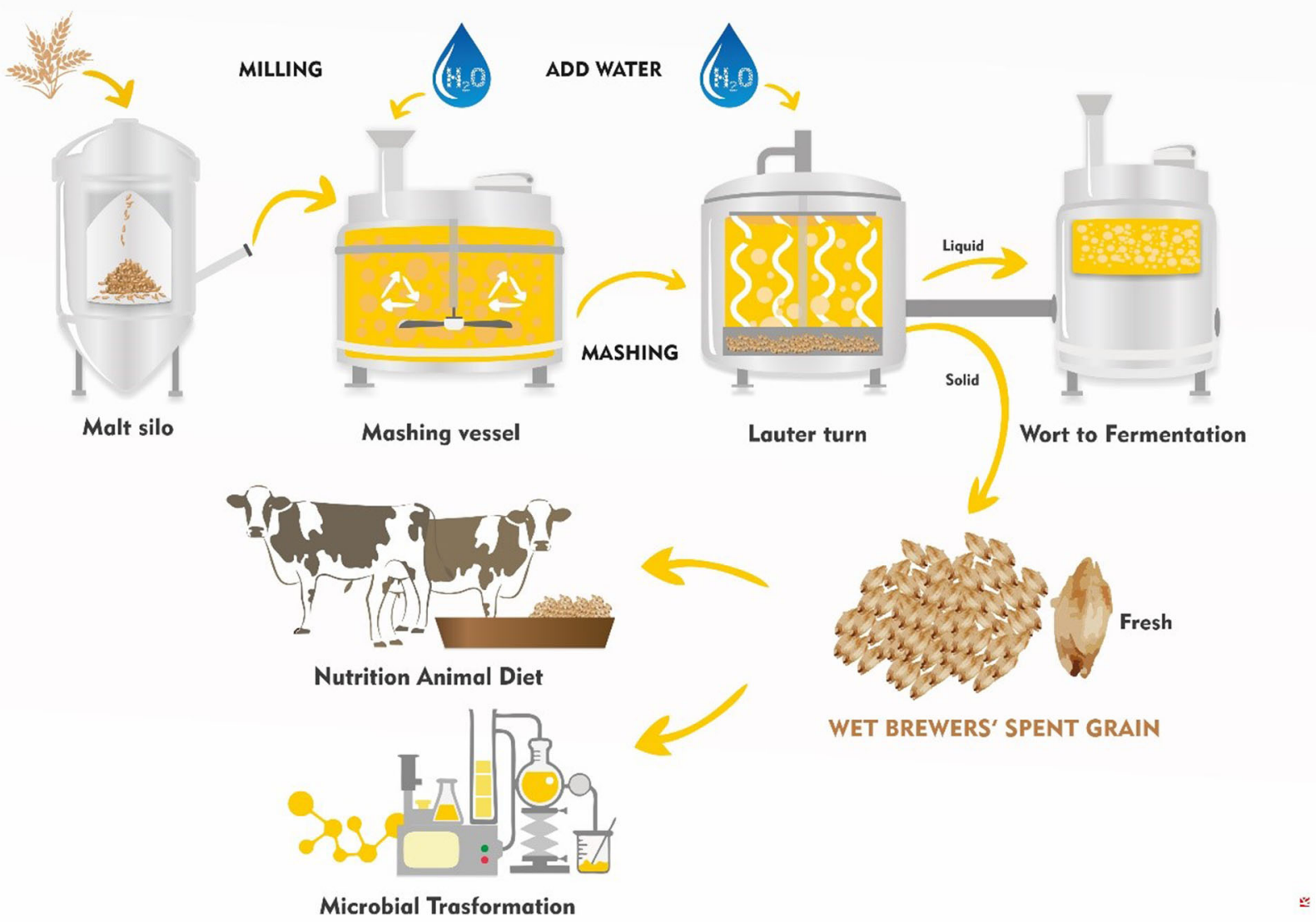

Fig. 1 Scheme of the brewing process and consecutive production of brewers' spent grain

Currently, the main solution for the exploitation of BSG continues to be its supply to local farmers for livestock feed. However, BSG production often exceeds the demand for local feed, which results in disposal issues in terms of the sustainability and environmental impact of breweries (Mussatto 2014). Research into new conservation systems and new uses and enhancement technologies, together with better understanding of the use of microorganisms as biocatalysts, are important in the search for new ways to exploit BSG in foods and animal feed, and in the pharmaceutical and cosmetic sectors. Consequently, patents have been filed recently in connection with BSG (Table 2), while others were originally filed from 1965.

In recent years, different aspects related to the chemical composition of BSG have been reviewed, from its use as a promising integrated feed source of prebiotic compounds for livestock (Lao et al. 2020) and a concentrate feed for lactating dairy cows (Chanie and Fievez 2017), to the best extraction methods to preserve its bio-active compounds (BonifácioLopes et al. 2019; Guido and Moreira 2017). In particular, the antioxidant, anti-atherogenic, anti-inflammatory, and anti-carcinogenic activities of chemical compounds in BSG have been considered (Ikram et al. 2017; Lynch et al. 2016; McCarthy et al. 2013). Finally, methods for exploitation of BSG in terms of food and energy production, and in the chemical and agronomic sectors have been reviewed (Cancelliere et al. 2019; Mussatto 2014; Xiros and Christakopoulos 2012; Aliyu and Bala 2011; Mussatto et al. 2006). In this context, the aim of this mini-review is to present the current literature on BSG from a microbiological point of view. Indeed, the knowledge of different BSG-related microbiological aspects is still limited, particularly when compared with the above-cited literature regarding the exploitation of its chemical components. However, BSG can support the growth of spoilage microorganisms as well as beneficial microorganisms, and these diverse microorganisms and their interactions can determine the safety aspects and full exploitation of BSG.

\section{Brewers' spent grain storage and stabilization}

Immediately after lautering, BSG has limited microbial contamination $\left(10^{2}-10^{3} \mathrm{CFU} \mathrm{g}^{-1}\right.$; Robertson et al. 2010a) and it can be considered as microbiologically stable and within 
Table 1 Chemical composition of brewers'spent grain

\begin{tabular}{|c|c|c|c|}
\hline Group & Units & Compound & Content \\
\hline \multirow[t]{13}{*}{ Major components } & \multirow[t]{13}{*}{$\mathrm{g} \mathrm{kg}^{-1}$ dry weight } & Cellulose (glucan) & $3-330$ \\
\hline & & Hemicellulose & $192-419$ \\
\hline & & Xylan & $136-206$ \\
\hline & & Arabinan & $56-419$ \\
\hline & & Starch & $10-120$ \\
\hline & & Lignin & $115-278$ \\
\hline & & Lipids & $30-106$ \\
\hline & & Proteins & $142-310$ \\
\hline & & Ashes & $11-46$ \\
\hline & & Extractives & $58-107$ \\
\hline & & Phenolics & $7-20$ \\
\hline & & Ferulic acid & $1860-1948$ \\
\hline & & $p$-Coumaric acid & $565-794$ \\
\hline \multirow[t]{19}{*}{ Minerals } & \multirow[t]{19}{*}{$\mathrm{mg} \mathrm{kg}^{-1}$ dry weight } & Silicon & $1400-10,740$ \\
\hline & & Phosphorus & $4600-6000$ \\
\hline & & Calcium & $2200-3515$ \\
\hline & & Magnesium & $1900-2400$ \\
\hline & & Sulfur & $1980-2900$ \\
\hline & & Potassium & $258.1-700.0$ \\
\hline & & Sodium & $100.0-309.3$ \\
\hline & & Iron & $100.0-193.4$ \\
\hline & & Zinc & $82.1-178.0$ \\
\hline & & Aluminum & $36.0-81.2$ \\
\hline & & Manganese & $40.9-51.4$ \\
\hline & & Cobalt & 17.8 \\
\hline & & Copper & $11.4-18.0$ \\
\hline & & Strontium & $10.4-12.7$ \\
\hline & & Iodine & 11 \\
\hline & & Barium & $8.6-13.6$ \\
\hline & & Chromium & $<0.5-5.9$ \\
\hline & & Molybdenum & 1.4 \\
\hline & & Boron & 3.2 \\
\hline \multirow[t]{11}{*}{ Non-essential amino acids } & \multirow[t]{11}{*}{$\%$ total protein } & Histidine & 26.27 \\
\hline & & Glutamic acid & 16.59 \\
\hline & & Aspartic acid & 4.81 \\
\hline & & Valine & 4.61 \\
\hline & & Arginine & 4.51 \\
\hline & & Alanine & 4.12 \\
\hline & & Serine & 3.77 \\
\hline & & Tyrosine & 2.57 \\
\hline & & Glycine & 1.74 \\
\hline & & Asparagine & 1.47 \\
\hline & & Glutamine & 0.07 \\
\hline \multirow[t]{6}{*}{ Essential amino acids } & \multirow[t]{6}{*}{$\%$ total protein } & Lysine & 14.31 \\
\hline & & Leucine & 6.12 \\
\hline & & Phenylalanine & 4.64 \\
\hline & & Isoleucine & 3.31 \\
\hline & & Threonine & 0.71 \\
\hline & & Tryptophan & 0.14 \\
\hline
\end{tabular}


Table 1 (continued)

\begin{tabular}{llll}
\hline Group & Units & Compound & Content \\
\hline Vitamins & ppm & Biotin & 0.1 \\
& & Choline & 1800 \\
& & Folic acid & 0.2 \\
& & Niacin & Phantotenic acid \\
& & Riboflavin & 8.5 \\
& & Thiamine & 0.7 \\
& & Pyridoxine & 0.7 \\
\hline
\end{tabular}

acceptable limits for food use. However, BSG takes several hours to cool down to room temperature $\left(20^{\circ} \mathrm{C}\right)$, and during this period microbial activity continues. The extensive changes in its structure that occur during malting and mashing make it accessible to hydrolytic enzymes, thus making BSG an easier substrate for microbial attack. Consequently, after only 5 days of storage at $20{ }^{\circ} \mathrm{C}$, the microbial concentrations can increase to $10^{6} \mathrm{CFU} \mathrm{g}^{-1}$, with microaerophilic, strictly anaerobic, and aerobic, mesophilic, and thermophilic bacteria representing the predominant naturally associated microflora (Robertson et al. 2010a, 2010b). In addition, filamentous fungi are frequently isolated after storage of BSG at room temperature, such as Aspergillus spp., Fusarium spp., Mucor spp., Penicillium spp., and Rhizopus spp. (Robertson et al. 2010a). Therefore, BSG must be stabilized and stored under the appropriate conditions if it is to be used at a later stage.

Many breweries are discouraged from drying BSG at $60^{\circ} \mathrm{C}$ due to the high associated energy costs (Aliyu and Bala 2011; Tang et al. 2009). Robertson et al. (2010b) compared different methods of BSG storage with respect to microbial proliferation, from the fresh material at $20^{\circ} \mathrm{C}$ to that refrigerated at $4{ }^{\circ} \mathrm{C}$, autoclaved at $120^{\circ} \mathrm{C}$ for $1 \mathrm{~h}$, and frozen. They reported that under storage at $4^{\circ} \mathrm{C}$ over 16 days, the numbers of aerobic bacteria in BSG remained $<10^{6} \mathrm{CFU} \mathrm{g}^{-1}$, while in the frozen and autoclaved samples, there was no evidence of microbial activity. Indeed, when it was stored at 4 and $20{ }^{\circ} \mathrm{C}$, BSG showed sugars loss that was ascribable to the activities of microbial enzymes, such as xylanases, esterases, and cellulases (Robertson et al. 2010b). Autoclaving was seen as effective for long-term BSG stability (Lynch et al. 2016).

\section{Brewers' spent grain in industrial biotechnology}

Brewers' spent grain is a valuable substrate for microbial growth, and it fulfills some of the requirements demanded for biotechnological exploitation, including regular availability and low market price. Bacteria, fungi, and yeast have been successfully used for the biotechnological exploitation of BSG to produce enzymes and metabolites, microbial biomass, pharmaceuticals, and substrates for biocontrol agents (Fig. 3). BSG has also been used as a substitute to expensive carbon sources for industrial production of lactic acid by Lactobacillus delbrueckii UFV H2B20 (Mussatto 2014; Mussatto et al. 2007, 2008), Lactobacillus pentosus CECT-
Fig. 2 Brewers' spent grain fresh from production and after drying
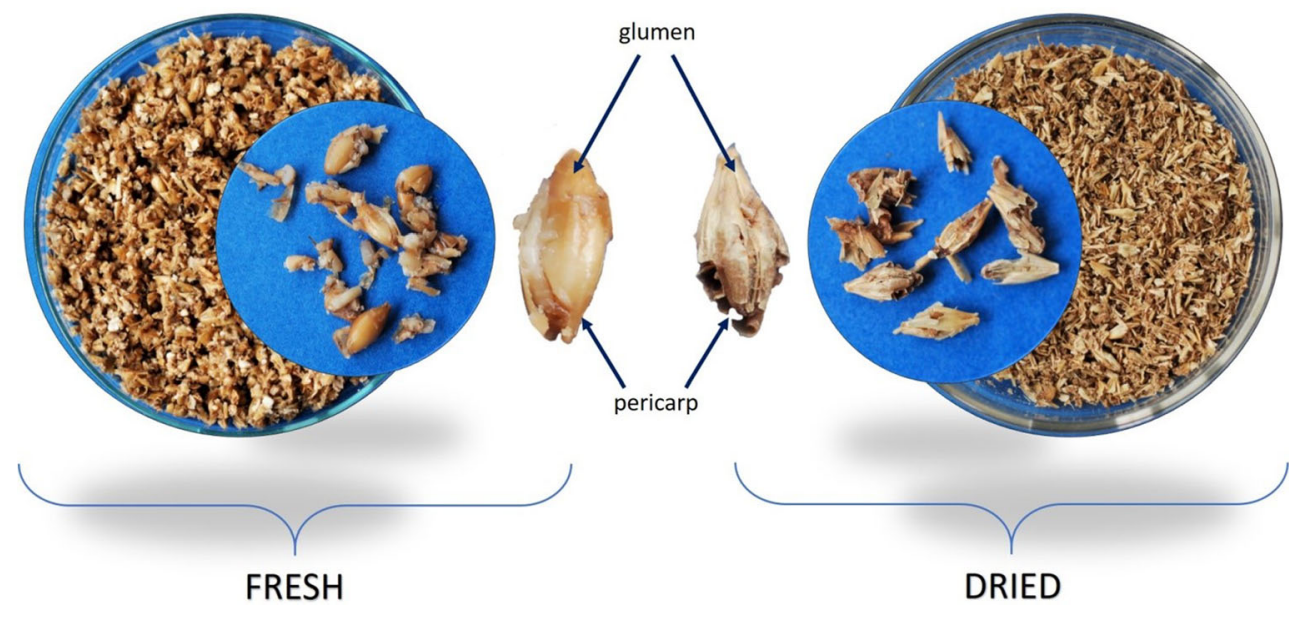


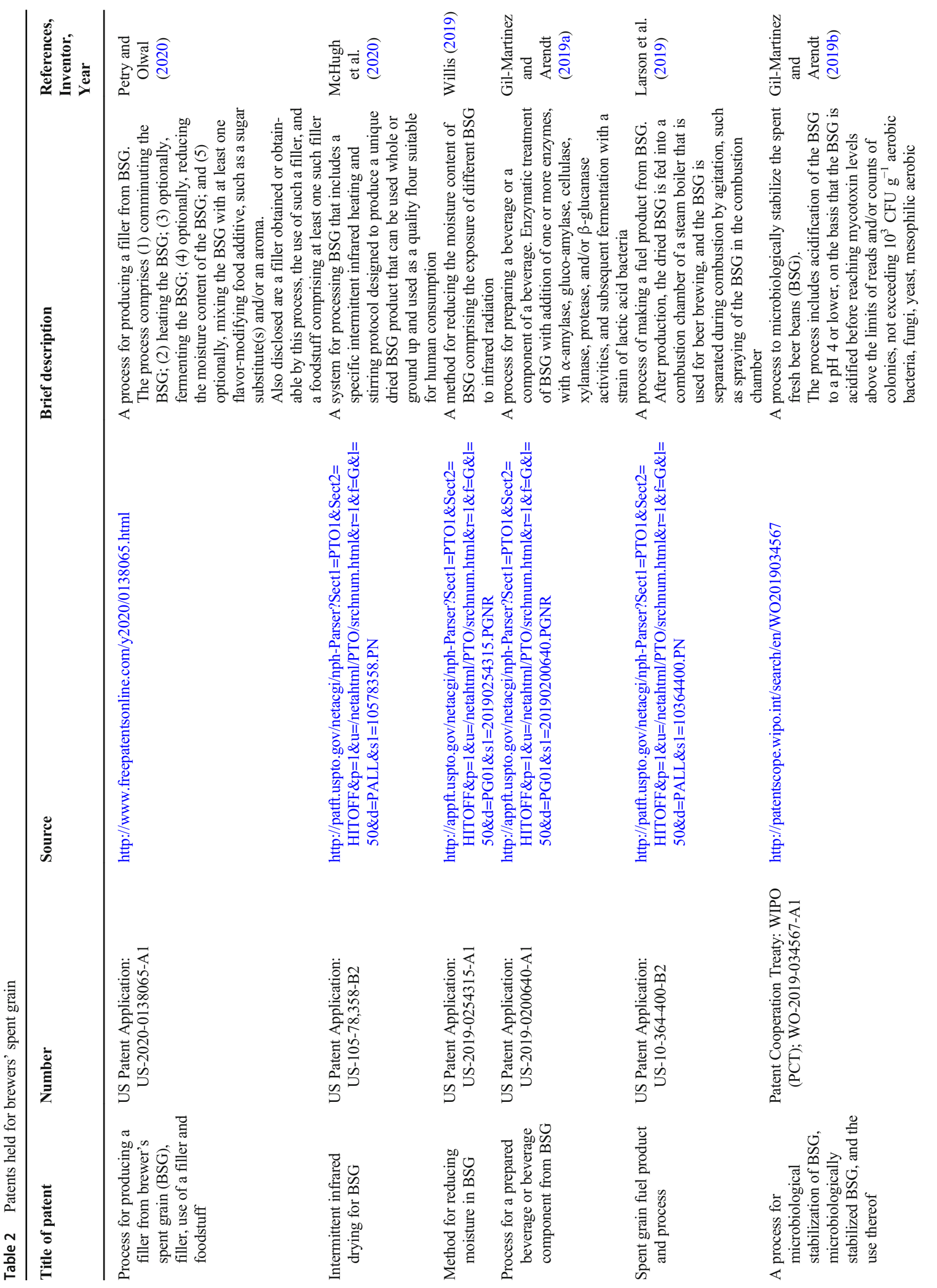




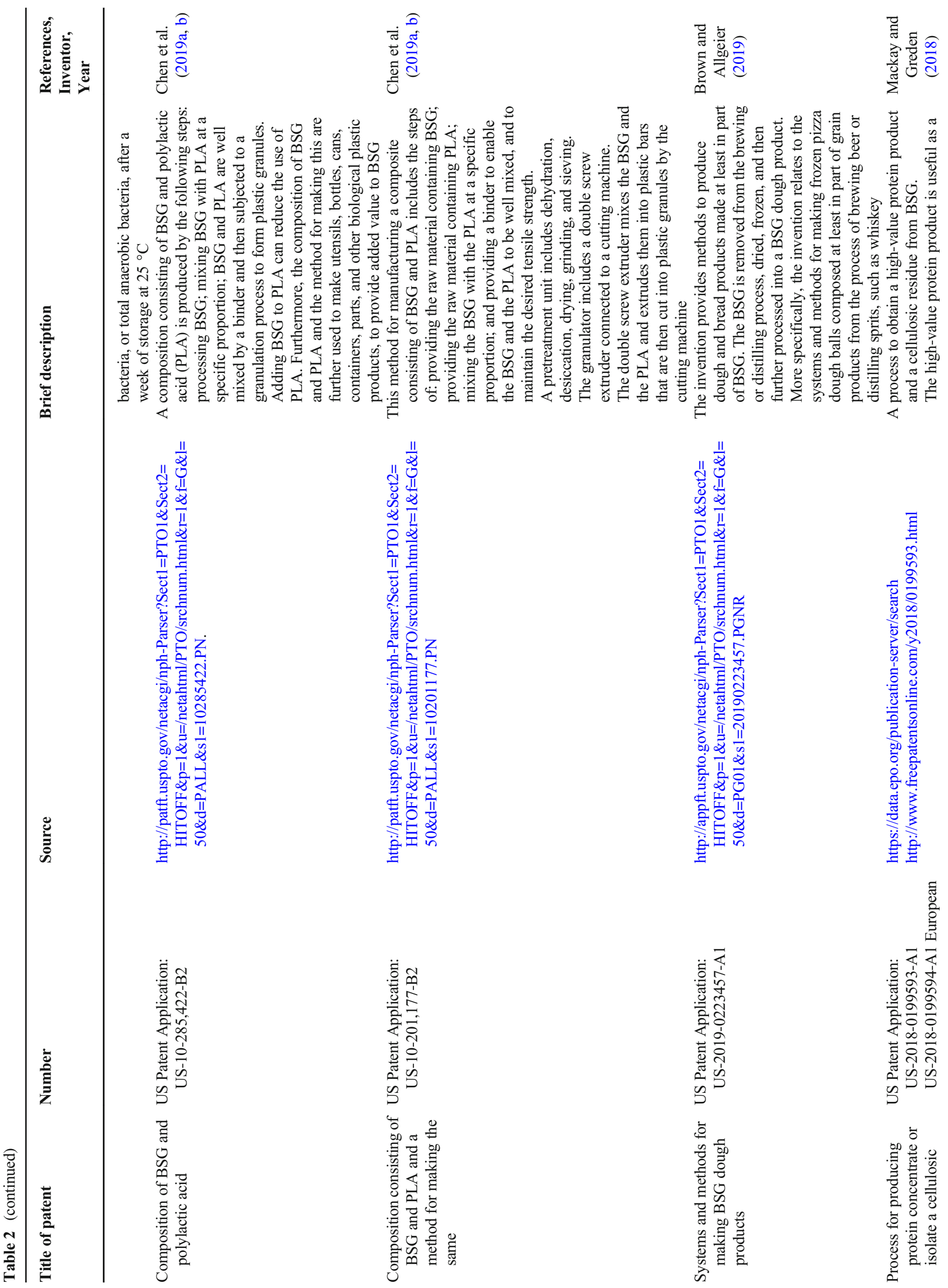




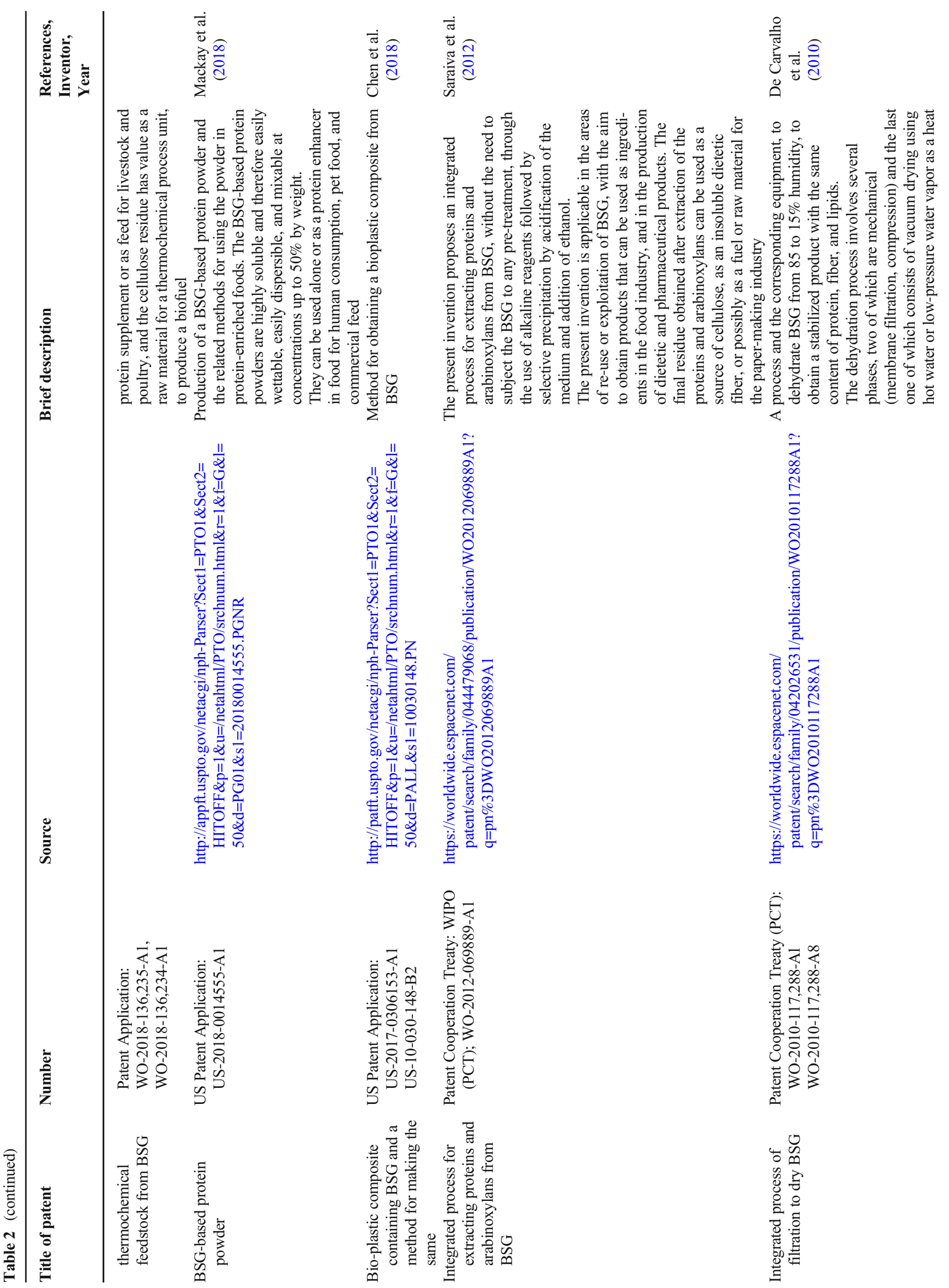




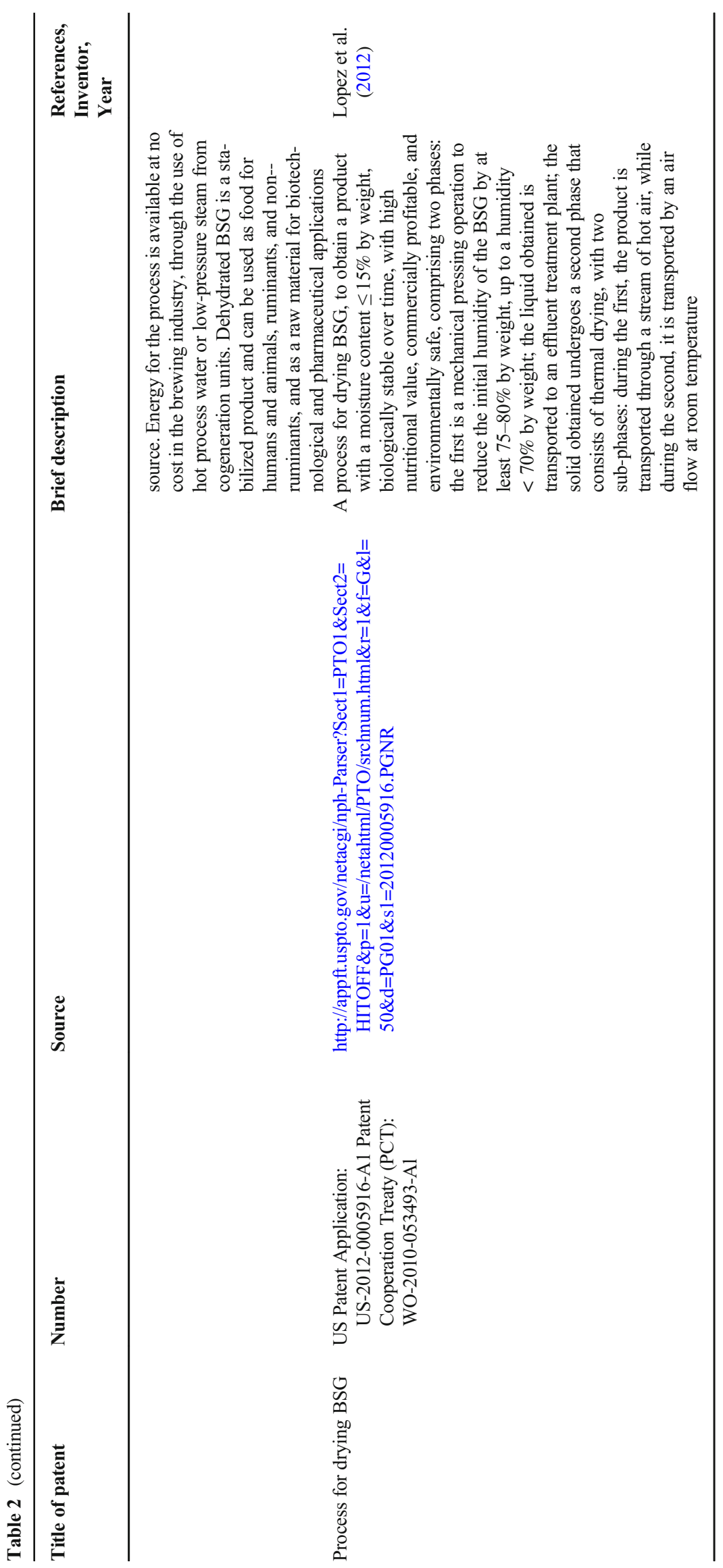


4023T, and Lactobacillus rhamnosus CECT-288 (Cruz et al. 2007).

Plaza et al. (2017) studied the feasibility of using BSG as a raw material to obtain butanol through an acetone-butanolethanol fermentation process using Clostridium beijerinckii DSM 6422. Although their results confirmed the suitability of BSG for the production of butanol, further studies are needed to scale-up this process. Neurospora crassa DSM 1129 and Fusarium oxisporum $\mathrm{F} 3$ isolated from cumin were used to convert the cellulose and hemicellulose in BSG directly into bio-ethanol, through successive phases of hydrolysis of the polysaccharides and fermentation of the monosaccharides (Xiros and Christakopoulos 2009; Xiros et al. 2008). The hydrolysis of BSG recalcitrant biopolymers (such as lignin and cellulose) during a pre-fermentation phase carried out by Aspergillus oryzae has been shown to improve the availability of nutrients, thus providing the complete requirements for growth of the yeast Rodosporidium toruloides (strain CBS 5490), a natural producer of carotenoids (Cooray et al. 2017).

Alternatively, the hydrolysis of BSG can be carried out through alkali, acid, hydrothermal, or enzymatic pretreatments (Rojas-Chamorro et al. 2020; Paz et al. 2019). Ethanologenic microorganisms have been used to produce ethanol from these hydrolyzed BSG, including Saccharomyces cerevisiae and Zigosaccharomyces rouxii (Liguori et al. 2015). In particular, the high gravity brewing yeast S. cerevisiae BLGII 1762 and S. cerevisiae PE-2 isolated from the Brazilian bioethanol industry produce ethanol with yields of between 23 and $81 \%$ (Pinheiro et al. 2019). In addition, hemicellulosic hydrolysates of BSG have been used to produce microbial biomass and xylitol using Debaryomyces hansenii CCMI 941 (Carvalheiro et al. 2007) and Candida guilliermondii FTI 20037 (Mussatto and Roberto 2005). Banjo et al. (2018) used BSG to produce ascorbic acid by submerged fermentation culture of Aspergillus flavus and Aspergillus tamari, whereby they obtained 6.25 and $7.25 \mathrm{~g} \mathrm{~L}^{-1}$ ascorbic acid, respectively.

Brewers' spent grain has also been used for isolation and maintenance of actinobacteria, such as Streptomyces coelicolor A3 (Szponar et al. 2003) and S. malaysiensis AMT-3, and their production of cellulases (Nascimento et al. 2009). Bacillus sp. KR-8104 has been grown on BSG to produce $\alpha$-amylase (Hashemi et al. 2011).

Regarding its exploitation in the pharmaceutical sector, BSG has been used as a culture medium for Cordyceps militaris (Gregori 2014) to produce cordycepin, a nucleoside analog with anti-tumor, anti-proliferative, anti-metastatic, insecticidal, and antibacterial activities (Gregori 2014). In addition, polysaccharides from $C$. militaris have shown significant antitumor activities against cervical and liver cancer cells in vitro (Yan et al. 2014), and extracts of its fruiting bodies show antioxidant, antibacterial, antifungal, and anti-tumor activities against human cell lines (Yan et al. 2014; Reis et al.
2013; Rao et al. 2010), and also anti-inflammatory (Rao et al. 2010), anti-fibrotic (Nan et al. 2001), anti-obesity (An et al. 2018), and anti-angiogenetic (Yoo et al. 2004) and insulinsecreting (Choi et al. 2004) activities. Thus, the use of BSG for cordycepin production by $C$. militaris has been shown to be a very effective technique for the production of high-value food and feed additives (Gregori 2014).

In recent years, the food industry has focused on the production of natural pigments from plants and microbial sources to overcome the use of synthetic pigments that can be hazardous to human health and to the environment. Silbir and Goksungur (2019) studied the production of natural red pigments by Monascus purpureus strain CMU001 in a submerged fermentation system using BSG as the raw substrate. Pigments from Monascus spp. have been used as natural coloring agents and natural food additives in eastern Asia, and have applications as pharmaceuticals, as they have been reported to have anti-mutagenic, anti-cancer, anti-obesity, antiinflammatory, anti-diabetes, and cholesterol-lowering activities (Silbir and Goksungur 2019).

\section{Brewers' spent grain in human and animal diets}

The ever-increasing world population and the consequent requests for more food to meet nutritional requirements are two of the factors that define the need for sustainable food production. In particular, the possibility to use waste from agroindustrial processes as raw materials to produce food and feed has drawn the attention of numerous researchers. In this context, BSG provides numerous compounds that can serve as the basis to produce functional food and feed (Bonifácio-Lopes et al. 2019; Skendi et al. 2018). Thus, the use of BSG as a substrate for microbial growth to produce single cell proteins, to enhance its techno-functional properties, and to increase its commercial value has been proposed (Connolly et al. 2019; He et al. 2019; Ibbett et al. 2019; Luft et al. 2019; Marson et al. 2019; Martín-García et al. 2019; Shen et al. 2019).

Single cell proteins are an important example of new healthy proteins with low environmental impact. Their sustainable production represents one of the possible solutions to the problem of protein supply for future generations (Finnigan et al. 2017; Suman et al. 2015). BSG can be used as a low-cost raw material to produce single cell proteins from non-mycotoxigenic filamentous fungi in a sustainable and economic way. Fungi such as Rhizopus spp., Trichoderma spp., and Mucor spp. have been shown to hydrolyze BSG to obtain nitrogen and carbon sources for their growth without the need for costly pre-treatments or enzymatic hydrolysis (Bekatorou et al. 2015).

Brewers' spent grain has been proposed as a food additive due to its beneficial nutritional properties. These are mainly 
due to the water-extractable part of BSG, which includes arabinoxylans (Mendis and Simsek 2014) and $\beta$-glucans (Steiner et al. 2015) that can regulate the gut microbiota. Possibly due to the release of xylo-oligosaccharides, arabinoxylans promote the growth of Bifidobacterium spp. and Lactobacillus spp., which have positive effects on the human gastrointestinal tract (Adamberg et al. 2014). Similarly, $\beta$-glucans can enhance growth and metabolic activity of beneficial microorganisms, such as Lactobacillus acidophilus, Lactobacillus casei, and Bifidobacterium animali subsp. lactis (Jayachandran et al. 2018). To further stimulate the grow of probiotic microorganisms, BSG has been used as a substrate to cultivate the fungus Pleurotus ostreatus, which represents an interesting source of $\beta$ glucans with prebiotic activities (Wang et al. 2001). In addition, it has been suggested that the intestinal microbiota, particularly Lactobacilli (e.g., L. salivarius, L. paracasei, L. rhamnosus) and Bifidobacteria (e.g., B. adolescentis, B. breve, $B$. longum), can partially degrade the lignin in BSG and metabolize the compounds released (Niemi et al. 2013). More recently, partial lignin degradation mediated by human fecal microbiota was shown in a colon intestine model (Ohraaho et al. 2016; Aura et al. 2013). Here, it was suggested that lactic acid bacteria can easily adapt in BSG-based broth, thus paving the way for the use of probiotic strains as starter cultures for further improvement of the bioactive properties of fermented BSG (Gupta et al. 2013).

In addition, phenolic acids of BSG have shown antimicrobial activities against pathogenic bacteria. Ferulic acid is active on Escherichia coli, Klebsiella pneumoniae, Enterobacter aerogenes, Citrobacter koseri, Pseudomonas aeruginosa, Helicobacter pylori, and Shigella sonnei (de Oliveira and Batista 2017). p-Coumaric acid inhibits several pathogenic bacteria, such as Staphylococcus aureus 6538, Streptococcus pneumoniae ATCC49619, Bacillus subtilis 9372, E. coli ATCC25922, Shigella dysenteriae 51302, and Salmonella typhimurium 50013 (Lou et al. 2012), and it contributes to the definition of the distribution and abundance of microbial populations in the digestive tract (Reverón et al. 2012).

The nutritional value of BSG can be increased through low-cost microbe-mediated transformation processes. Natural degraders of lignocellulosic materials have been reported to significantly increase the nutritional content of BSG by fermentation (e.g., Aspergillus spp., Trichoderma spp., Fusarium spp., Neurospora spp.) (Bekatorou et al. 2007). Solid-state fermentation of BSG with Rhizopus oligosporus CCT 4134 and Rhizopus microsporus var. oligosporus (DMSZ1964) successfully increased the levels of amino acids, citric acid, vitamins, and antioxidants, and reduced the levels of carbohydrates, fats, and dietary fiber (Cooray and Chen 2018; Canedo et al. 2016). Further optimization of the operating parameters of solid-state fermentation can significantly increase the protein content, soluble protein, antioxidant and antibacterial activities, and total phenolic content, all of which are characteristics that are highly appreciated for feed and food applications (Ibarruri et al. 2019). Bacillus subtilis WX-17 (NCIMB 15204) isolated from a traditional food in Japan has been used for enrichment of the BSG content of triglycerides, palmitic, oleic, linoleic and stearic acids, polyphenols, and flavonoids (Tan et al. 2019).

Data on the digestive parameters and fecal microbial composition of dogs have also suggested that BSG can be used as a source of fiber in the canine diet (Eisenhauer et al. 2019). Also, recently, BSG was used as a substrate to rear different insects, such as the black soldier fly larva (Hermetia illucens) and mealworm larva (Tenebrio molitor) (Mancini et al. 2019; Melis et al. 2019; Shumo et al. 2019). These studies have confirmed that it is possible to take advantage of BSG to produce a nutrient-rich feed derived from the black soldier fly larva (Mancini et al. 2019; Melis et al. 2019; Shumo et al. 2019). Microbiological analyses of the larvae reared on the different substrates indicated that BSG administration resulted in decreases in Staphylococci, yeast, and mold, and the absence of bacterial endospores (Mancini et al. 2019).

\section{Brewers' spent grain in agriculture}

Brewers' spent grain has valuable applications in agriculture. It has been proposed as a promising substrate for production of biocontrol agents, such as the entomopathogenic fungus Beauveria bassiana, which is active against Galleria mellonella (Qiu et al. 2019). In particular, the high content of starch and fiber in BSG facilitates the germination and mycelial growth of $B$. bassiana conidia. Moreover, B. bassiana produced metabolites that promote plant growth (Qiu et al. 2019).

Brewers' spent grain has direct applications for the soil. Here, BSG increases organic substances, stability of aggregates, water retention, and available water, and also lowers the $\mathrm{C} / \mathrm{N}$ ratio, which favors mineralization (Aboukila et al. 2018; Mbagwu and Ekwealor 1990). Addition of BSG for an earthworm diet produced enriched soil in Paenibacillaceae, Enterobacteriaceae, Chitinophagaceae, and Comamonadaceae (Budroni et al. 2020). In particular, the low $\mathrm{pH}$ and high organic carbon content of BSG were associated with higher abundance of bacterial taxa involved in cellulose degradation and showed high assimilation of ammonia and nitrates. When applied to bioremediation of soil polluted by engine oil, BSG enhanced plant growth and encouraged microbial degradation of hydrocarbons, using bacteria such as Acinetobacter spp., Micrococcus spp., Pseudomonas spp., Nocardia spp., and Bacillus spp. (Abioye et al. 2010). In particular, with the addition of BSG, the counts of hydrocarbon- 


\section{BREWERS' SPENT GRAIN}

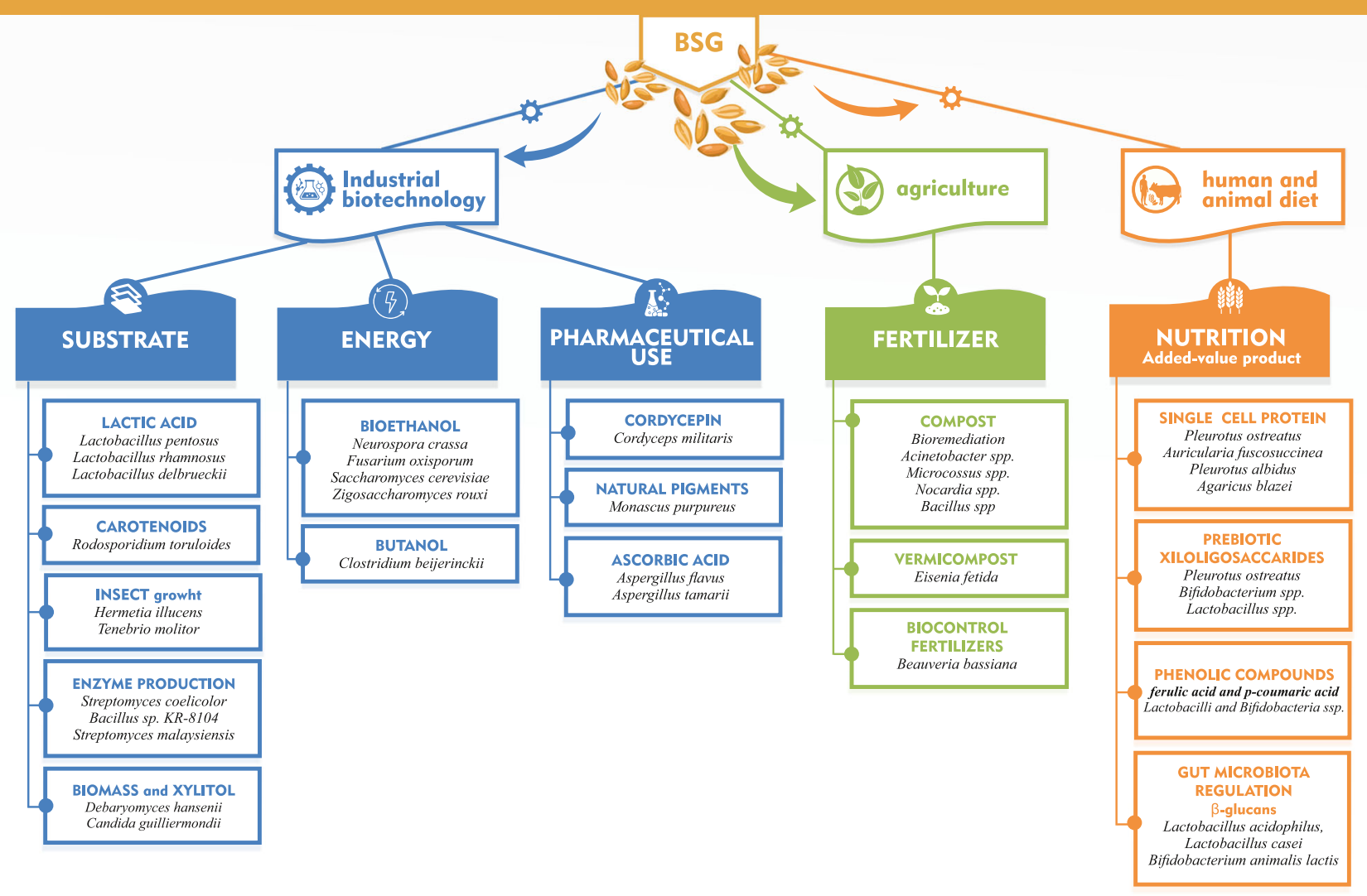

Fig. 3 Microbial exploitation of brewers' spent grain in industrial biotechnology, agricultural processes, and human and animal diets

using bacteria in the soil were about $5 \%$ higher than those without BSG addition.

Brewers' spent grain was recently used for vermicomposting by the earthworm Eisenia fetida, to produce a biological fertilizer (Saba et al. 2019). The vermicompost obtained from BSG respected the parameters of the safety laws: E. coli and Salmonella spp. were absent in $25 \mathrm{~g}$ of the vermicompost, and mycotoxins were degraded during its formation, with ochratoxin A levels below the legal limits. The enzymatic activities revealed a strict link between the microbiota and the quality of the BSG vermicompost, as the higher abundance of fungi and yeast in the BSG vermicompost was accompanied by increased dehydrogenase activity.

\section{Safety issues}

As BSG has been proposed as a component of human and animal nutrition, and also plant nutrition, it is necessary to consider some of the microbiological parameters that influence the quality of this raw material, such as the presence of pathogenic microorganisms and mycotoxins.

\section{Pathogenic microorganisms}

Most potential contaminants of beer originate from the raw materials and/or unclean brewing equipment. The raw materials used in brewing include malt, hops, and occasionally brewing water, and these can be contaminated by microorganisms that must be killed during the brewing process, to prevent wort and beer spoilage (Hill 2009). Correct hygienic standards and regular maintenance must be observed, so that the entire beer production process is not microbiologically compromised (Obi 2017). Water must be free of pathogenic microorganisms, such as coliform bacteria, E. coli, Aerobacter aerogenes, Salmonella/Shigella spp., and Vibrio cholerae (Hill 2009). However, to date, no known human pathogens have been found to survive in BSG after the brewing process.

\section{Mycotoxins}

Mycotoxins are secondary metabolites that are produced by fungi and that can affect human and animal health, due to their neurotoxic, immunosuppressive, teratogenic, and carcinogenic effects (Varga et al. 2015). Contamination of food and beverages by 


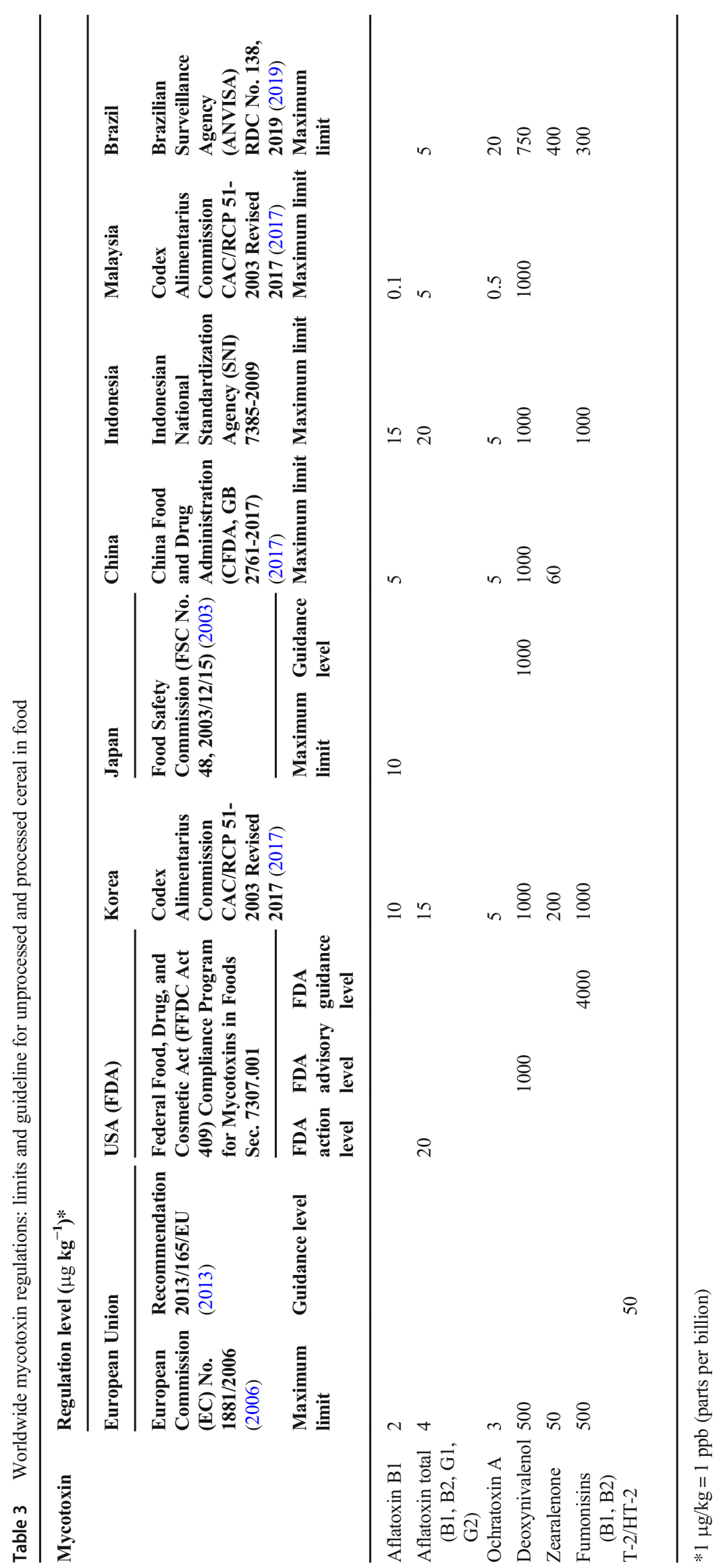




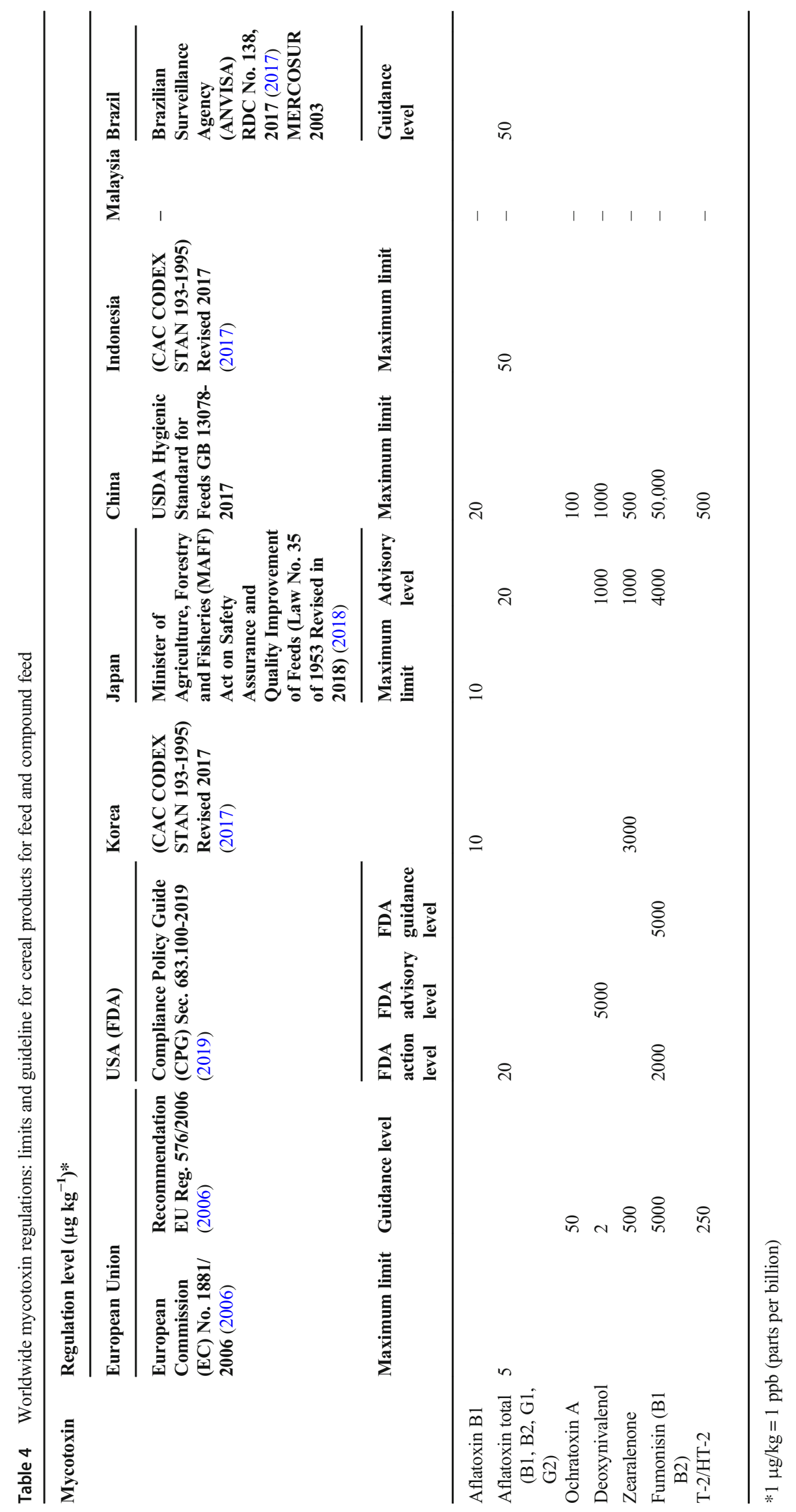


mycotoxins is a serious and recurrent problem worldwide, which results in economic losses and health concerns. Several studies have highlighted the need to monitor and determine the exact types and amounts of mycotoxins in cereals and their endproducts and by-products, to ensure food and feed safety (Mastanjević et al. 2019; Habschied et al. 2014). Therefore, worldwide legal limits of mycotoxins have been established (Tables 3 and 4).

The contamination of malt by mycotoxigenic fungi and mycotoxins can occur throughout the entire brewer production chain, from the field to the malting and brewing (Bianco et al. 2019, 2018; Mastanjević et al. 2018). Mycotoxigenic fungal species that belong to the genera Aspergillus spp. (e.g., aflatoxin, ochratoxin A), Fusarium spp. (e.g., T-2 toxin, deoxynivalenol, fumonisins), Penicillium (e.g., ochratoxin A, patulin), and Alternaria spp. (e.g., alternariol) have been frequently isolated from barley kernels, malted barley, and BSG (Gonzalez Pereyra et al. 2011 ). Consequently, deoxynivalenol, aflatoxins, fumonisins, trichothecenes, ochratoxin $\mathrm{A}$, and zearalenone are the most significant mycotoxins in the beer chain (Pascari et al. 2018; Habler et al. 2017; Bertuzzi et al. 2011).

Although the concentrations of mycotoxins decrease significantly during the production process (e.g., deoxynivalenol, zearalenone) (Piacentini et al. 2019), BSG can be contaminated by fungi after its production, which will result in increased levels of mycotoxins. Members of the genus Fusarium have been frequently isolated in high numbers in BSG, including $F$. verticilloides $(50 \%), F$. proliferatum $(25 \%), F$. equiseti $(12.5 \%)$, and $F$. oxysporum (12.5\%) (Mastanjević et al. 2019). Fusarium spp. produce the large group of mycotoxins known as the trichotecenes. Further, fumonisins B1 and AFB1 have been detected in malt barley and BSG, which appear to be produced during storage (Gonzalez Pereyra et al. 2011; Kensler et al. 2011). Eight mycotoxins were reported to be produced by $F$. culmorum (i.e., fusarenone-X, 3acetyldeoxynivalenol, diacetoxyscirpenol, T-2, HT-2, deoxynivalenol, nivalenol, zearalenone), and these have been studied during the production of beer and for its various byproducts (i.e., wastewater, spent yeast, BSG) (Mastanjević et al. 2018; Habschied et al. 2014). Malting and brewing byproducts can also be contaminated by combinations of mycotoxins and multi-toxins (Mastanjević et al. 2019, 2018; Krstanović et al. 2015; Habschied et al. 2014, 2011). Lotaustraline and tryptophol have been reported at high levels in cereals and in yeast starters used for brewing (Mastanjević et al. 2018). Other mycotoxins and multi-toxins that have been detected in malt and brewing by-products include aurofusarin, beauvericin, brevianamide $\mathrm{F}$, chrysogine, culmorine, 5hydroxyculmorine, 15-hydroxyculmorine, deoxynivalenol, deoxynivalenol-3-glucoside, linamarin, tentoxine, and zearalenone (Mastanjević et al. 2019).

\section{Conclusions}

Brewers' spent grain is the main by-product of the brewing industry, and it is regularly available in large amounts at a low market price. Moreover, it is an interesting raw material due to its richness in valuable compounds and nutrients, and the availability of processes for its stabilization. These are all key factors for development of a plethora of different applications that span from the bio/technological production of added-value goods, functional foods, and animal feed, to the generation of other goods of interest for the pharmaceutical and agricultural sectors. Accordingly, there is great interest on BSG exploitation, as indicated by the number of patents concerning BSG preservation, use as a source of useful compounds, and bioconversion (Table 2).

A better understanding of the potential of microorganisms as biocatalysts for BSG transformation is essential for its recycling and exploitation, and also with a view to reduction of its carbon footprint under the concept of a circular economy. Therefore, we might see further interesting new BSGbased applications in the future. In particular, given the biotechnological and health importance of the various microbial groups that have been isolated from BSG, it is essential to study the metabolic relationships among the different microbial communities, and their influences on the final transformation of BSG, to exclude, or on the contrary, to favor, these new processes.

Author contributions A.B., G.Z., and M.B.: conceptualization. F.F., M.B., and G.Z.: software. A.B. and M.B.: resources. A.B., F.F., G.Z., and M.B.: writing - original draft preparation. I.M., S.Z., G.Z., A.B., and M.B.: writing - review and editing. I.M. and S.Z.: visualization. M.B.: supervision. All authors have read and approved the final manuscript.

Funding information Open access funding provided by Università degli Studi di Sassari within the CRUI-CARE Agreement. This research received no external funding. A.B. gratefully acknowledges University of Sassari for the financial support by a $\mathrm{PhD}$ research grant. G.Z. gratefully acknowledges Sardinia Regional Government for the financial support of his research grant (Regional Operational Program of the European Social Fund (ROP ESF) 2014-2020-C.U.P. J86C18000270002).

\section{Compliance with ethical standards}

This article does not contain any studies with human participants or animals performed by any of the authors.

Conflict of interest The authors declare that they have no conflicts of interest.

Open Access This article is licensed under a Creative Commons Attribution 4.0 International License, which permits use, sharing, adaptation, distribution and reproduction in any medium or format, as long as you give appropriate credit to the original author(s) and the source, provide a link to the Creative Commons licence, and indicate if changes were made. The images or other third party material in this article are included in the article's Creative Commons licence, unless indicated otherwise in a 
credit line to the material. If material is not included in the article's Creative Commons licence and your intended use is not permitted by statutory regulation or exceeds the permitted use, you will need to obtain permission directly from the copyright holder. To view a copy of this licence, visit http://creativecommons.org/licenses/by/4.0/.

\section{References}

Abioye PO, Aziz AA, Agamuthu P (2010) Enhanced biodegradation of used engine oil in soil amended with organic wastes. Water Air Soil Pollut 209(1-4):173-179

Aboukila EF, Nassar IN, Rashad M, Hafez M, Norton JB (2018) Reclamation of calcareous soil and improvement of squash growth using brewers' spent grain and compost. J Saudi Soc Agric Sci 17(4):390-397

Adamberg S, Sumeri I, Uusna R, Ambalam P, Kondepudi KK, Adamberg K, Ljungh A (2014) Survival and synergistic growth of mixed cultures of bifidobacteria and lactobacilli combined with prebiotic oligosaccharides in a gastrointestinal tract simulator. Microb Ecol Health Dis 25(1):23062. https://doi.org/10.3402/mehd.v25. 23062

Aliyu S, Bala M (2011) Brewer's spent grain: a review of its potentials and applications. Afr J Biotechnol 103(3):324-331

An Y, Li Y, Wang X, Chen Z, Xu H, Wu L, Liu M (2018) Cordycepin reduces weight through regulating gut microbiota in high-fat dietinduced obese rats. Lipids Health Dis 17(1):1-10

ANVISA Brazilian Health Surveillance Agency (2019) RDC No 329/ 2019, http://portal.anvisa.gov.br/documents/10181/3427171/RDC 3262019 .pdf/3dfc1310-3eef-4efe-9046-6dbfae73a8b1

ANVISA Brazilian Health Surveillance Agency (2017) RDC No 138/ $2017 \mathrm{http} / /$ portal.anvisa.gov.br/documents/10181/3219534/RDC 1382017 .pdf/

Assobirra (2018) Annual Report for the year 2017. http://www. assobirra.it

Aura AM, Niemi P, Mattila I, Niemelä K, Smeds A, Tamminen T, Faulds C, Buchert J, Poutanen K (2013) Release of small phenolic compounds from Brewer's spent grain and its lignin fractions by human intestinal microbiota in vitro. J Agric Food Chem 61(40):9744-9753

Banjo TT, Kareem SO, Popoola TO, Akinloye OA (2018) Microbial production of ascorbic acid from brewery spent grain (BSG) by Aspergillus flavus and Aspergillus tamari. Food Appl Biosci J 6(2):93-105

Bekatorou A, Bountas Y, Banat IM, Kanellakl M (2007) Upgrading brewer's spent grains by treatment with Aspergillus species. Chem Ind Chem Eng Q /CICEQ 13(2):72-78

Bekatorou A, Plessas S, Mantzourani I (2015) Biotechnological exploitation of brewery solid wastes for recovery or production of valueadded products. In: Ravishankar RV (ed) Advances in food biotechnology, 1st edn. Wiley, West Sussex, pp 393-414. https://doi.org/ 10.1002/101002/9781118864463ch24

Bertuzzi T, Rastelli S, Mulazzi A, Donadini G, Pietri A (2011) Mycotoxin occurrence in beer produced in several European countries. Food Control 22(12):2059-2064

Bianco A, Fancello F, Balmas V, Dettori M, Motroni A, Zara G, Budroni M (2019) Microbial communities and malt quality of durum wheat used in brewing. J Inst Brew 125(2):222-229

Bianco A, Fancello F, Balmas V, Zara G, Dettori M, Budroni M (2018) The microbiome of Sardinian barley and malt. J Inst Brew 124(4): 344-351

Birsan RI, Wilde P, Waldron KW, Rai DK (2019) Recovery of polyphenols from brewer's spent grains. Antioxidants 8(9):380. https://doi. org/10.3390/antiox 8090380

Bonifácio-Lopes T, Teixeira JA, Pintado M (2019) Current extraction techniques towards bioactive compounds from brewer's spent grain: a review. Crit Rev Food Sci Nutr:1-12. https://doi.org/10.1080/ 10408398.2019.1655632

Brown T, Allgeier M (2019) Systems and methods for making spent grain dough products. US Patent 16,167,503, 25 July 2019

Budroni M, Mannazzu I, Zara S, Saba S, Pais A, Zara G (2020) Composition and functional profiling of the microbiota in the casts of Eisenia fetida during vermicomposting of brewers' spent grains. Biotechnol Rep 25:e00439. https://doi.org/10.1016/j.btre.2020. e00439

Cancelliere R, Carbone K, Pagano M, Cacciotti I, Micheli L (2019) Biochar from brewers' spent grain: a green and low-cost smart material to modify screen-printed electrodes. Biosensors 9(4):139. https://doi.org/10.3390/bios9040139

Canedo MS, de Paula FG, Da Silva FA, Vendruscolo F (2016) Protein enrichment of brewery spent grain from Rhizopus oligosporus by solid-state fermentation. Bioprocess Biosyst Eng 39(7):1105-1113

Carvalheiro F, Duarte LC, Medeiros R, Gírio FM (2007) Xylitol production by Debaryomyces hansenii in brewery spent grain dilute-acid hydrolysate: effect of supplementation. Biotechnol Lett 29(12): 1887-1891

Chanie D, Fievez V (2017) Review on preservation and utilization of wet brewery spent grain as concentrate replacement feed for lactating dairy cows. J Anim Health Prod 5(1):10-13

Chen SM, Shih YF, Jhang WC (2019a) Composition consisting of brewer's spent grains and polylactic acid. US Patent 10, 285,422, 14 May 2019

Chen SM, Shih YF, Jhang WC (2019b) Composition consisting of brewer's spent grains and polylactic acid and a method for making the same. US Patent 10,201,177, 12 Feb 2019

Chen SM, Shih YF, Jhang WC (2018) Bio-plastic composite containing brewer's spent grains and a method for making the same. US Patent 10,030,148, 24 July 2018

CFDA China Food and Drug Administration (2017) National food safety standard for maximum levels of mycotoxins in foods GB 27612017, National Health and Family Planning Commission Notice No. 4 of 2017

Choi SB, Park CH, Choi MK, JUN DW, PARK S (2004) Improvement of insulin resistance and insulin secretion by water extracts of Cordyceps militaris, Phellinus linteus and Paecilomyces tenuipes in $90 \%$ pancreatectomized rats. Biosci Biotechnol Biochem 68(11):2257-2264

Codex Alimentarius, C (2017) General standard for contaminants and toxins in food and feed. Codex stand, 193-1995. World Health Organization http://www.fao.org/input/download/standards/17/ CXS 193e 2015.pdf

Codex Alimentarius, C (2014) Code of practice for the prevention and reduction of mycotoxin contamination in cereals. CAC/RCP 512003. Adopted 2003. Revised 2014. World Health Organization. http://www.fao.org/input/download/standards/406/CXP 051e 2014.pdf

Commission Directive (EC) No 100/2008 of 28 October 2008 amending Council Directive 90/496/EEC on nutrition labelling for foodstuffs as regards recommended daily allowances, energy conversion factors and definitions. Off J Eur Union L 285, 2008, pp. 9-12

Commission Recommendation (EC) No 165/2013 of 27 March 2013 on the presence of T-2 and HT-2 toxin in cereals and cereal products. Off J Eur Union L 91, 2013, pp. 12-15

Commission Recommendation (EC) No 576/2006 of 17 August 2006 on the presence of deoxynivalenol, zearalenone, ochratoxin A, T-2 and HT-2 and fumonisins in products intended for animal feeding. Off J Eur Union L229, 2006, pp. 7-9

Commission Regulation (EC) No 1881/2006 of 19 December 2006 setting maximum levels for certain contaminants in foodstuffs. Off $\mathrm{J}$ Eur Union L 364, 2006, pp. 5-24

Connolly A, Cermeño M, Crowley D, O'Callaghan Y, O'Brien NM, FitzGerald RJ (2019) Characterisation of the in-vitro bioactive 
properties of alkaline and enzyme extracted brewers' spent grain protein hydrolysates. Food Res Int 121:524-532. https://doi.org/ 10.1016/j.foodres.2018.12.008

Cooray ST, Chen WN (2018) Valorization of brewer's spent grain using fungi solid-state fermentation to enhance nutritional value. J Funct Foods 42:85-94. https://doi.org/10.1016/j.jff.2017.12.027

Cooray ST, Lee JJ, Chen WN (2017) Evaluation of brewers' spent grain as a novel media for yeast growth. AMB Express 7(1):1-10

Cruz JM, Moldes AB, Bustos G, Torrado A, Domínguez JM (2007) Integral utilization of barley husk for the production of food additives. J Sci Food Agric 87(6):1000-1008

De Carvalho JMR, De Matos Machado R, Rodrigues RAD, Henriques CMC, de Magalhâes Correia PFM (2010) Integrated process of filtration to dry BSG. WIPO (PCT) WO 2010/117288A1, 14 Oct 2010

de Oliveira SE, Batista R (2017) Ferulic acid and naturally occurring compounds bearing a feruloyl moiety: a review on their structures occurrence and potential health benefits. Compr Rev Food Sci Food Saf 16(4):580-616

dos Santos Mathias TR, de Mello PPM, Sérvulo EFC (2014) Solid wastes in brewing process: a review. J Brew Distill 5(1):1-19

EFSA Panel on Dietetic Products Nutrition and Allergies (NDA) (2011) Scientific opinion on health claims already evaluated (ID 215568 674712139816331974419141924193423643354698 4704) pursuant to Article 13 (1) of Regulation (EC) No 1924/2006. EFSA J 9(6):2203. https://doi.org/10.2903/j.efsa.2011.2203

Eisenhauer L, Vahjen W, Dadi T, Kohn B, Zentek J (2019) Effects of brewer's spent grain and carrot pomace on digestibility fecal microbiota and fecal and urinary metabolites in dogs fed low- or highprotein diets. J Anim Sci 97(10):4124-4133

European Union Commission Regulation N ${ }^{\circ}$ 432/2012 of 16 May 2012 establishing a list of permitted health claims made on foods other than those referring to the reduction of disease risk and to children's development and health. Off J Eur Union L 136, 25,5,2012 p 1-40

European Union Commission Directive 2002/32/EC OJEC L140/10 [(accessed on 8 January 2019)]; Available online: https://eurlexeuropaeu/resourcehtml?uri=cellar:aca28b8c-bf9d-444fb470268f71df28fb000402/DOC_1\&format=PDF

European Union Recommendation 2006/576/EC OJEC L229/7 Available online: https://eur-lexeuropaeu/LexUriServ/ LexUriServdo?uri=OJ:L:2006:229:0007:0009:EN:PDF (accessed on 8 January 2019)

European Union Recommendation 2013/165/EC OJEC L 91 12-15 Available online: https://eur-lexeuropaeu/LexUriServ/ LexUriServdo?uri=OJ:L:2013:091:0012:0015:EN:PDF (accessed on 8 January 2019)

Fărcas A, Tofană M, Socaci S, Mudura E, Scrob S, Salanță L, Mureșan V (2014) Brewers' spent grain - a new potential ingredient for functional foods. J Agroaliment Process Technol 20(2):137-141

Finnigan T, Needham L, Abbott C (2017) Mycoprotein: a healthy new protein with a low environmental impact. In: Nadathur SR, Wanasundara JPD, Scanlin L (eds) Sustainable protein sources. Academic Press, San Diego, pp 305-325. https://doi.org/10.1016/ B978-0-12-802778-3.00019-6

Food Safety Commission (2003) Law No. 48, 23 May, 2003/12/15 https://www.fsc.go.jp/sonota/fsb_law160330.pdf

Gil-Martinez J, Arendt E (2019a) Process for prepared a beverage or beverage component from brewer's spent grains. US patent 16 , 322,475, 4 July 2019

Gil-Martinez J, Arendt E (2019b) A process for microbiological stabilisation of BSG, microbiologically stabilised BSG, and the use thereof. WIPO (PCT) WO 034567A1, 21 Feb 2019

Gonzalez Pereyra ML, Rosa CAR, Dalcero AM, Cavaglieri LR (2011) Mycobiota and mycotoxins in malted barley and brewer's spent grain from Argentinean breweries. Lett Appl Microbiol 53(6):649_ 655
Gregori A (2014) Cordycepin production by Cordyceps militaris cultivation on spent brewery grains. Acta Biol Slov 57(2):45-52

Guido LF, Moreira MM (2017) Techniques for extraction of brewer's spent grain polyphenols: a review. Food Bioprocess Technol 10(7):1192-1209

Gupta M, Abu-Ghannam N, Gallaghar E (2010) Barley for brewing: characteristic changes during malting brewing and applications of its by-products. Compr Rev Food Sci Food Saf 9(3):318-328

Gupta S, Jaiswal AK, Abu-Ghannam N (2013) Optimization of fermentation conditions for the utilization of brewing waste to develop a nutraceutical rich liquid product. Ind Crop Prod 44:272-282

Habler K, Gotthardt M, Schüler J, Rychlik M (2017) Multi-mycotoxin stable isotope dilution LC-MS/MS method for Fusarium toxins in beer. Food Chem 218:447-454

Habschied K, Šarkanj B, Krstanović V, Velić N, Novak M, Mastanjević K (2014) Fusarium mycotoxins in malting and brewing by-products. In Proceedings of the World Mycotoxin Forum 8th conference Mycotoxin control: the system approach. Vienna Austria 10-12 November 2014

Habschied K, Šarkanj B, Klapec T, Krstanović V (2011) Distribution of zearalenone in malted barley fractions dependent on Fusarium graminearum growing conditions. Food Chem 129(2):329-332

Hashemi M, Razavi SH, Shojaosadati SA, Mousavi SM (2011) The potential of brewer's spent grain to improve the production of $\alpha$ amylase by Bacillus sp KR-8104 in submerged fermentation system. New Biotechnol 28:165-172

He Y, Kuhn DD, Ogejo JA, O'Keefe SF, Fraguas CF, Wiersema BD, Jin Q, Yu D, Huang H (2019) Wet fractionation process to produce high protein and high fiber products from brewer's spent grain. Food Bioprod Process 117:266-274

Hill AE (2009) Microbiological stability of beer. In: Bamforth C (ed) Beer a quality perspective. Academic Press, Elsevier, Cambridge, pp 163-184

Ibarruri J, Cebrián M, Hernández I (2019) Solid state fermentation of brewer's spent grain using Rhizopus sp to enhance nutritional value. Waste Biomass Valoriz 10(12):3687-3700

Ibbett R, White R, Tucker G, Foster T (2019) Hydro-mechanical processing of brewers' spent grain as a novel route for separation of protein products with differentiated techno-functional properties. Innov Food Sci Emerg Technol 56:102184. https://doi.org/10.1016/ jifset2019102184

Ikram S, Huang L, Zhang H, Wang J, Yin M (2017) Composition and nutrient value proposition of brewers spent grain. J Food Sci 82(10): 2232-2242

Jayachandran M, Chen J, Chung SSM, Xu B (2018) A critical review on the impacts of $\beta$-glucans on gut microbiota and human health. $J$ Nutr Biochem 61:101-110

Kensler TW, Roebuck BD, Wogan GN, Groopman JD (2011) Aflatoxin: a 50-year odyssey of mechanistic and translational toxicology. Toxicol Sci 120(1):S28-S48

Krstanović V, Mastanjević K, Velić N, Pleadin J, Perši N, Španić V (2015) The influence of Fusarium culmorum contamination level on deoxynivalenol content in wheat malt and beer. Rom Biotech Lett 20(5):10901

Kunze W (2004) Brewing Malting. Vlb, Berlin, pp 18-152

Lao EJ, Dimoso N, Raymond J, Mbega ER (2020) The prebiotic potential of brewers' spent grain on livestock's health: a review. Trop Anim Health Prod 52:461-472

Larson GL, Holmes C, Smith BM, Wilson DD (2019) Spent grain fuel product and process. US Patent 10,364,400, 30 July 2019

Liguori R, Soccol C, Porto de Souza Vandenberghe L, Woiciechowski A, Faraco V (2015) Second generation ethanol production from brewers' spent grain. Energies 8(4):2575-2586

Lynch KM, Steffen EJ, Arendt EK (2016) Brewers' spent grain: a review with an emphasis on food and health. J Inst Brew 122:553-568 
Lopez B, Copello A, Pontiggia RM, Fernandez H (2012) Process for drying brewer's spent grains. US Patent 13,127,819, 12 Jan 2012

Lou Z, Wang H, Rao S, Sun J, Ma C, Li J (2012) P-Coumaric acid kills bacteria through dual damage mechanisms. Food Control 25(2): $550-554$

Luft L, Confortin TC, Todero I, da Silva JRF, Tovar LP, Kuhn RC, Jahn SL, Treichel H, Mazutti MA (2019) Ultrasound technology applied to enhance enzymatic hydrolysis of brewers' spent grain and its potential for production of fermentable sugars. Waste Biomass Valoriz 10:2157-2164

MAFF Ministry of Agriculture, Forestry and Fisheries (2018) Act No. 35 of 1953 . Act on safety assurance and quality improvement of feeds. Ordinance No 82 of 27 Dec 2018, Ministerial ordinance on the specifications and standards of feeds and feed additives. http:// www.famic.go.jp/ffis/feed/obj/sianhou_eng.pdf

Mackay I, Greden K (2018) Process for producing protein concentrate or isolate and cellulosic thermochemical feedstock from brewer's spent grains US Patent 1571512119 July 2018

Mackay I, Greden K, Mingus JD, Toboja K (2018) Brewer's spent-grain based protein powder. US patent 15,651,389, 18 Jan 2018

Mancini S, Fratini F, Turchi B, Mattioli S, Dal Bosco A, Tuccinardi T, Nozic S, Paci G (2019) Former foodstuff products in Tenebrio molitor rearing: effects on growth chemical composition microbiological load and antioxidant status animals. 9(8):484

Marson GV, Machado MTDC, de Castro RJS, Hubinger MD (2019) Sequential hydrolysis of spent brewers' yeast improved its physicochemical characteristics and antioxidant properties: a strategy to transform waste into added-value biomolecules. Process Biochem 84:91-102

Martín-García B, Pasini F, Verardo V, Díaz-De-cerio E, Tylewicz U, Gómez-Caravaca AM, Caboni MF (2019) Optimization of sonotrode ultrasonic-assisted extraction of proanthocyanidins from brewers' spent grains antioxidants. 8(8):282

Mastanjević K, Šarkanj B, Warth B, Krska R, Sulyok M, Mastanjević K, Krstanović V (2018) Fusarium culmorum multi-toxin screening in malting and brewing by-products. LWT 98:642-645

Mastanjević K, Šarkanj B, Šantek B, Krstanović V (2019) Fusarium culmorum mycotoxin transfer from wheat to malting and brewing products and by-products. World Mycotoxin J 12(1):55-66

Mbagwu JSC, Ekwealor GC (1990) Agronomic potential of brewers' spent grains. Biol Wastes 34:335-347

McCarthy AL, O'Callaghan YC, Piggott CO, FitzGerald RJ, O'Brien NM (2013) Brewers' spent grain; bioactivity of phenolic component its role in animal nutrition and potential for incorporation in functional foods: a review. Proc Nutr Soc 72:117-125

McHugh TH, Bustillos RDA, Olson DA, Pan Z, Kurzrock DJ, Schwartz JL (2020) Intermittent infrared drying for brewery-spent grain. US patent 10,578,358, 3 Mar 2020

Melis R, Braca A, Sanna R, Spada S, Mulas G, Fadda ML, Sassu MM, Serra G, Anedda R (2019) Metabolic response of yellow mealworm larvae to two alternative rearing substrates. Metabolomics 15(8):113

Mendis M, Simsek S (2014) Arabinoxylans and human health. Food Hydrocoll 42:239-243

Mussatto SI (2014) Brewers' spent grain: a valuable feedstock for industrial applications. J Sci Food Agric 94(7):1264-1275

Mussatto SI, Dragone G, Roberto IC (2006) Brewers' spent grain: generation characteristics and potential applications. J Cereal Sci 43(1): $1-14$

Mussatto SI, Dragone G, Roberto IC (2007) Ferulic and p-coumaric acids extraction by alkaline hydrolysis of brewer's spent grain. Ind Crop Prod 25(2):231-237

Mussatto SI, Roberto IC (2005) Acid hydrolysis and fermentation of brewer's spent grain to produce xylitol. J Sci Food Agric 85(14): 2453-2460
Mussatto SI, Fernandes M, Mancilha IM, Roberto IC (2008) Effects of medium supplementation and $\mathrm{pH}$ control on lactic acid production from brewer's spent grain. Biochem Eng 40(3):437-444

Nan JX, Park EJ, Yang BK, Song CH, Ko G, Sohn DH (2001) Antifibrotic effect of extracellular biopolymer from submerged mycelial cultures of Cordyceps militaris on liver fibrosis induced by bile duct ligation and scission in rats. Arch Pharm Res 24:327-332

Nascimento R, Junior N, Pereira N, Jr Bon E, Coelho R (2009) Brewer's spent grain and corn steep liquor as substrates for cellulolytic enzymes production by Streptomyces malaysiensis. Lett Appl Microbiol 48:529-535

Niemi P, Aura AM, Maukonen J, Smeds AI, Mattila I, Niemela K, Tamminen T, Faulds CB, Buchert J, Poutanen K (2013) Interactions of a lignin-rich fraction from brewers' spent grain with gut microbiota in vitro. J Agric Food Chem 61:6754-6762

Obi CN (2017) Brewery contaminants challenges and remedies - a review. Nigerian J Microbiol 31(1):3926-3940

Ohra-aho T, Niemi P, Aura AM, Orlandi M, Poutanen K, Buchert J, Tamminen T (2016) Structure of brewer's spent grain lignin and its interactions with gut microbiota in vitro. J Agric Food Chem 64(4):812-820

Pascari X, Ramos AJ, Marín S, Sanchís V (2018) Mycotoxins and beer. Impact of beer production process on mycotoxin contamination. A review. Food Res Int 103:121-129

Paz A, Outeiriño D, Guerra NP, Domínguez JM (2019) Enzymatic hydrolysis of brewers' spent grain to obtain fermentable sugars. BioresourTechnol 275:402-409

Plaza PE, Gallego-Morales LJ, Peñuela-Vásquez M, Lucas S, GarcíaCubero MT, Coca M (2017) Biobutanol production from brewers' spent grain hydrolysates by Clostridium beijerinckii. Bioresour Technol 244:166-174

Petry C, Olwal M (2020) Process for producing a filler from brewer's spent grain filler use of a filler and foodstuff. US Patent 16,610,545, 7 May 2020

Piacentini KC, Rocha LO, Savi GD, Carnielli-Queiroz L, De Carvalho FL, Correa B (2019) Assessment of toxigenic Fusarium species and their mycotoxins in brewing barley grains. Toxins 11(1):31

Pinheiro T, Coelho E, Romaní A, Domingues L (2019) Intensifying ethanol production from brewers' spent grain waste: use of whole slurry at high solid loadings. New Biotechnol 53:1-8

Qiu L, Li JJ, Li Z, Wang JJ (2019) Production and characterization of biocontrol fertilizer from brewers' spent grain via solid-state fermentation. Sci Rep 9(1):480

Rao YK, Fang SH, Wu WS, Tzeng YM (2010) Constituents isolated from Cordyceps militaris suppress enhanced inflammatory mediator's production and human cancer cell proliferation. J Ethnopharmacol 131(2):363-367

Reis FS, Barros L, Calhelha RC, Ćirić A, Van Griensven LJ, Soković M, Ferreira IC (2013) The methanolic extract of Cordyceps militaris (L) Link fruiting body shows antioxidant antibacterial antifungal and antihuman tumor cell lines properties. Food Chem Toxicol 62:91-98

Reverón I, de Las Rivas B, Muñoz R, López de Felipe F (2012) Genomewide transcriptomic responses of a human isolate of Lactobacillus plantarum exposed to p-coumaric acid stress. Mol Nutr Food Res 56(12):1848-1859

Robertson JA, I'Anson KJ, Treimo J, Faulds CB, Brocklehurst TF, Eijsink VG, Waldron KW (2010a) Profiling brewers' spent grain for composition and microbial ecology at the site of production. LWT-Food Sci Technol 43(6):890-896

Robertson JA, I'Anson KJ, Brocklehurst TF, Faulds CB, Waldron KW (2010b) Effect of storage conditions on the microbial ecology and biochemical stability of cell wall components in brewers' spent grain. J Agric Food Chem 58(12):7266-7272

Rojas-Chamorro JA, Romero-García JM, Cara C, Romero I, Castro E (2020) Improved ethanol production from the slurry of pretreated 
brewers' spent grain through different co-fermentation strategies. Bioresour Technol 296:122367. https://doi.org/10.1016/j.biortech. 2019.122367

Saba S, Zara G, Bianco A, Garau M, Bononi M, Deroma M, Pais A, Budroni M (2019) Comparative analysis of vermicompost quality produced from brewers' spent grain and cow manure by the red earthworm Eisenia fetida. Bioresour Technol 293:122019. https:// doi.org/10.1016/j.biortech.2019.122019

Santos M, Jimenez JJ, Bartolome B, Gomez-Cordoves C, del Nozal MJ (2003) Variability of brewers' spent grain within a brewery. Food Chem 80:17-21

Saraiva AJM, Coimbra Rodrigues Da Silva MA, De Castro Pinho OM; Ferreira Vieria EM, Martins Rocha MA, Pinto Leite Viegas Oliveira Ferreira IM (2012) Integrated process for extracting proteins and arabinoxylans from brewer's spent grain. WO 2012/069889A1, 31 May 2012

Szponar B, Pawlik KJ, Gamian A, Dey ES (2003) Protein fraction of barley spent grain as a new simple medium for growth and sporulation of soil actinobacteria. Biotechnol Lett 25(20):1717-1721

Silbir S, Goksungur Y (2019) Natural red pigment production by Monascus purpureus in submerged fermentation systems using a food industry waste: brew spent grain. Foods 8(5):161

Shen Y, Abeynayake R, Sun X, Ran T, Li J, Chen L, Yang W (2019) Feed nutritional value of brewers' spent grain residue resulting from protease aided protein removal. J Anim Sci Biotechnol 10(1):78

Shumo M, Osuga IM, Khamis FM, Tanga CM, Fiaboe KKM, Subramanian S, Ekesi S, van Huis A, Borgemeister C (2019) The nutritive value of black soldier fly larvae reared on common organic waste streams in Kenya. Sci Rep 9(1):1-13

Steiner J, Procopio S, Becker T (2015) Brewers' spent grain: source of value-added polysaccharides for the food industry in reference to the health claims. Eur Food Res Technol 241:303-315

Skendi A, Harasym J, Galanakis CM (2018) Recovery of high addedvalue compounds from brewing and distillate processing by-products. In: Galanakis CM (ed) Sustainable recovery and reutilization of cereal processing by-products, 1st edn. Elsevier, Woodhead Publishing, pp 189-225

Suman G, Nupur M, Anuradha S, Pradeep B (2015) Single cell protein production: a review. Int J Curr Microbiol App Sci 4(9):251-262

Tan YX, Mok WK, Lee J, Kim J, Chen WN (2019) Solid state fermentation of brewers' spent grains for improved nutritional profile using Bacillus subtilis wx-17. Fermentation 5(3):52

Tang D, Yin G, He Y, Hu S, Li B, Li L, Liang H, Borthakur D (2009) Recovery of protein from brewers' spent grain by ultrafiltration. Biochem Eng J 48:1-5
US Food and Drug Administration (2001) Guidance for industry: fumonisin levels in human foods and animal feeds; Final Guidance. US FDA, Silver Spring

US Food and Drug Administration (2010) Guidance for industry and FDA: advisory levels for deoxynivalenol (DON) in finished wheat products for human consumption and grains and grain by-products used for animal feed. US FDA, Silver Spring

US Food and Drug Administration (2019) Action levels for aflatoxin in animal feeds. CPG 7126(33):384

Varga J, Baranyi N, Chandrasekaran M, Vágvölgyi C, Kocsubé S (2015) Mycotoxin producers in the Aspergillus genus: an update. Acta Biol Szeged 59(2):151-167

Wang D, Sakoda A, Suzuki M (2001) Biological efficiency and nutritional value of Pleurotus ostreatus cultivated on spent beer grain Bioresour Technol 78(3):293-300

Wang B, Luo Y, Myung KH, Liu JX (2014) Effects of storage duration and temperature on the chemical composition microorganism density and in vitro rumen fermentation of wet brewers' grain. Asian Australas J Anim Sci 27(6):832

Willis GJ (2019) Method of reducing moisture in brewers' spent grain. US Patent 15,965,747, 22 Aug 2019

Xiros C, Topakas E, Katapodis P, Christakopoulos P (2008) Evaluation of Fusarium oxysporum as an enzyme factory for the hydrolysis of brewer's spent grain with improved biodegradability for ethanol production. Ind Crop Prod 28(2):213-224

Xiros C, Christakopoulos P (2009) Enhanced ethanol production from brewer's spent grain by a Fusarium oxysporum consolidated system. Biotechnol Biofuels 2(1):4

Xiros C, Christakopoulos P (2012) Biotechnological potential of brewer's spent grain and its recent applications. Waste Biomass Valori 3(2): 213-232

Yan JK, Wang WQ, Wu JY (2014) Recent advances in Cordyceps sinensis polysaccharides: mycelial fermentation isolation structure and bioactivities: a review. J Funct Foods 6:33-47

Yoo HS, Shin JW, Cho JH, Son CG, Lee YW, Park SY, Cho CK (2004) Effects of Cordyceps militaris extract on angiogenesis and tumor growth. Acta Pharm Sin 25(5):657-665

Zupančič GD, Panjičko M, Zelić B (2017) Biogas production from brewer's yeast using an anaerobic sequencing batch reactor. Food Technol Biotechnol 55(2):187-196

Publisher's note Springer Nature remains neutral with regard to jurisdictional claims in published maps and institutional affiliations. 